\title{
Pengaruh Osmopriming Benih terhadap Pertumbuhan dan Morfofisiologi Tanaman Kangkung Darat (Ipomoea reptans Poir) pada Cekaman Kekeringan
}

\section{The Effect of Seed Osmopriming on Growth and Morphophysiology of Kangkoong (Ipomoea reptans Poir) in Drought Stress}

\author{
Annisa Latifa* dan Diah Rachmawati \\ 'Departemen Biologi Tropika, Fakultas Biologi, Universitas Gadjah Mada \\ J1. Teknika Selatan Sekip Utara, Yogyakarta 55281, Indonesia \\ Diterima 30 Juni 2020/Disetujui 30 Juli 2020
}

\begin{abstract}
Drought stress is one of the inhibiting factors in the cultivation of kangkoong (Ipomoea reptans Poir). Solutions to overcome that problems are seed osmopriming. This experiment aimed to investigate the effect of seed osmopriming on the growth and morphophysiology of kangkoong in drought stress. The experiment was conducted from September 2015 to April 2016 at the Plant Physiology Laboratory and FALITMA of Universitas Gadjah Mada, Yogyakarta. This experiment used a randomized block design with two treatments, namely seed osmopriming $(0 \%, 5 \%, 10 \%$, and $15 \%(w / v)$ PEG 6000) and drought stress (watering interval of 1,3, and 5 days). The observation traits were germination percentage, germination rate, germination synchronization, root length, root dry weight, crown dry weight, leaf chlorophyll content, and leaf proline content. Statistical analysis included analyses of variance followed by DMRT at a confidence level of 95\%. The results showed that a concentration of $15 \%$ PEG significantly increased germination percentage, germination rate, germination synchronization, root length, roots dry weight, crowns dry weight, leaves proline content, and concentration of $10 \%$ PEG significantly increased leaves chlorophyll content in drought stress. Seed osmopriming was effectively used to overcome drought stress problem on the cultivation of kangkoong.
\end{abstract}

Keywords: germination percentage, PEG 6000, root length, watering interval

\section{ABSTRAK}

Cekaman kekeringan merupakan salah satu faktor penghambat dalam budidaya tanaman kangkung darat (Ipomoea reptans Poir). Salah satu solusi dalam mengatasi masalah tersebut adalah melalui teknik osmopriming benih. Penelitian ini bertujuan untuk mengetahui pengaruh osmopriming benih terhadap pertumbuhan dan morfofisiologi tanaman kangkung darat pada cekaman kekeringan. Penelitian dilaksanakan pada bulan September 2015 sampai April 2016 di Laboratorium Fisiologi Tumbuhan dan FALITMA, Universitas Gadjah Mada, Yogyakarta. Penelitian ini menggunakan rancangan acak kelompok (RAK) dengan dua faktor perlakuan yaitu osmopriming benih $(0 \%, 5 \%, 10 \%$, dan $15 \%$ (w/v) PEG 6000) dan cekaman kekeringan (interval penyiraman 1, 3, dan 5 hari sekali). Peubah yang diamati adalah persentase berkecambah, kecepatan berkecambah, keserempakan berkecambah, panjang akar, bobot kering akar, bobot kering tajuk, kadar klorofil, serta kadar prolin. Analisis statistik meliputi sidik ragam dan dilanjutkan dengan uji jarak berganda duncan (DMRT) pada taraf kepercayaan 95\%. Hasil menunjukkan bahwa osmopriming meningkatkan secara signifikan persentase berkecambah, kecepatan berkecambah, keserempakan berkecambah, panjang akar, bobot kering akar, bobot kering tajuk, dan kadar prolin dengan konsentrasi PEG 15\%, serta meningkatkan secara signifikan kadar klorofil dengan konsentrasi PEG 10\% pada cekaman kekeringan. Osmopriming benih efektif digunakan untuk mengatasi masalah cekaman kekeringan pada budidaya tanaman kangkung darat (Ipomoea reptans Poir).

Kata kunci: interval penyiraman, panjang akar, PEG 6000, persentase berkecambah

\footnotetext{
* Penulis untuk korespondensi. e-mail: nisalatifa24@gmail.com
} 


\section{PENDAHULUAN}

Tanaman sayuran yang banyak dibudidayakan oleh petani di Indonesia salah satunya adalah kangkung darat (Ipomoea reptans Poir). Tanaman kangkung darat memiliki rasa yang enak dan mengandung vitamin $\mathrm{A}$, vitamin $\mathrm{C}$, serta mineral terutama zat besi (Sunarjono, 2013). Selain memiliki kandungan nilai gizi yang tinggi, tanaman ini juga memiliki potensi pasar yang besar sejalan dengan meningkatnya jumlah penduduk dan kesadaran masyarakat akan pentingnya gizi.

Faktor yang menjadi kendala dalam memproduksi tanaman kangkung darat adalah kemarau panjang yang mengakibatkan terjadinya kekeringan. Cekaman kekeringan merupakan suatu kondisi dimana kadar air tanah berada pada kondisi yang minimum untuk pertumbuhan dan produksi tanaman. Cekaman kekeringan dapat disebabkan oleh rendahnya curah hujan, rendahnya penyimpanan air tanah, dan laju transpirasi yang melebihi pemasukan air pada tanaman (Rao et al., 2006). Cekaman kekeringan pada tumbuhan dapat dibedakan menjadi tiga, yaitu cekaman ringan, sedang, dan berat. Cekaman ringan ditandai dengan adanya beberapa gangguan pada aktivitas biosintesis yaitu dalam menghasilkan komponen-komponen dinding sel, klorofil, enzim-enzim, dan protein. Cekaman sedang ditandai dengan penurunan yang lebih jauh pada tekanan turgor yang berakibat pada menyempitnya celah stomata dan terjadi penurunan yang progresif pada aktivitas fotosintesis (Fitter dan Hay, 2002). Pengaruh dari cekaman kekeringan tersebut tidak hanya menekan pertumbuhan dan hasil tetapi juga dapat menyebabkan kematian pada tanaman.

Solusi dalam menghadapi cekaman kekeringan adalah dengan menggunakan teknik priming pada benih sebelum ditanam. Menurut Chen dan Arora (2011), priming memperkuat sistem antioksidan dan meningkatkan potensial perkecambahan biji yang berakibat pada meningkatnya toleransi terhadap stres. Priming menghasilkan seedling yang lebih sehat dan kuat sehingga tanaman dapat tumbuh lebih cepat di lapangan serta terhindar dari penyakit atau tekanan lain dalam proses perkembangannya. Seedling yang lebih kuat memiliki kemampuan yang lebih baik dalam bertahan terhadap kondisi stres.

Pada priming, biji direndam dalam larutan yang potensial osmotiknya tinggi sehingga aktivitas metabolik pra-perkecambahan terus berlanjut, sedangkan kemunculan radikula dicegah dan selanjutnya dikeringkan kembali sampai pada tingkat kelembaban semula (Debbarma dan Das, 2017). Menurut Hussian et al. (2014), aktivitas metabolik yang berlangsung pada fase I perkecambahan yaitu perbaikan DNA dan mitokondria serta sintesis protein menggunakan mRNA sedangkan pada fase II berlangsung sintesis mitokondria dan protein dengan translasi mRNA serta pengubahan cadangan makanan seperti protein, lemak, dan lipid menjadi senyawa yang dibutuhkan untuk perkecambahan.

Salah satu teknik priming yang sering digunakan adalah osmopriming. Osmopriming adalah teknik merendam biji selama periode tertentu dalam suatu larutan gula,
PEG, dan lain-lainnya yang selanjutnya dikeringanginkan sebelum ditanam. Osmopriming tidak hanya meningkatkan perkecambahan biji tetapi juga meningkatkan hasil panen dalam kondisi salin maupun non salin (Debbarma dan Das, 2017). Osmopriming dengan PEG $0.1 \mathrm{~g} \mathrm{~mL}^{-1} \mathrm{H}_{2} \mathrm{O}$ dapat meningkatkan persentase perkecambahan biji, indeks perkecambahan, daya berkecambah, indeks vigor semaian, panjang semaian, dan bobot kering semaian serta menurunkan rerata waktu perkecambahan secara signifikan dibandingkan dengan kontrol (tanpa perlakuan) pada biji bunga matahari (El-Saidy et al., 2011) serta $\mathrm{KNO}_{3} 1 \%$ dapat meningkatkan persentase perkecambahan, persentase kemunculan semaian, tinggi semaian, dan bobot kering semaian secara signifikan dibandingkan dengan kontrol pada biji cowpea (Vigna unguiculata (L.) Walp.) (Singh et al., 2014). Penelitian Erinnovita et al. (2008) menunjukkan bahwa perlakuan priming dengan $\mathrm{CaCl}_{2}$ 1.25 $\mathrm{MPa}$ memberikan hasil terbaik dalam meningkatkan daya tumbuh benih kacang panjang dibandingkan dengan perlakuan lainnya dan kontrol.

Priming dapat mengatasi dampak yang ditimbulkan oleh stres kekeringan. Hal tersebut sebagaimana penelitian Matsushima dan Sakagami (2013) pada biji padi yang menunjukkan bahwa hydropriming dapat mempersingkat waktu perkecambahan secara signifikan, meningkatkan bobot kering pucuk, bobot kering akar, panjang pucuk, dan laju pemanjangan pucuk secara signifikan dibandingkan dengan kontrol (tanpa perlakuan) pada berbagai tingkat kelembaban tanah. Gorzi et al. (2018) menemukan bahwa priming dengan kombinasi $1 \mathrm{mM} \mathrm{SA}, 0.5 \% \mathrm{Fe}, 0.5 \% \mathrm{Zn}$ pada biji Stevia (Stevia rebaudiana) menunjukkan nilai persentase perkecambahan, laju perkecambahan, panjang semaian, indeks vigor semaian, klorofil, aktivitas CAT, dan aktivitas POD maksimum dibandingkan dengan perlakuan lain dan kontrol pada semua tingkat stres kekeringan $(0,-3$, -6, dan -9 bar). Dampak positif dari priming tersebut juga ditunjukkan pada penelitian Pinheiro et al. (2018) yaitu meningkatnya persentase perkecambahan dengan $50 \mathrm{ppm}$ $\mathrm{GA}_{3}$ serta meningkatnya indeks kecepatan perkecambahan pada biji sorghum genotip $B R S-330$ dan $L-20$, pertumbuhan akar, dan keseimbangan rasio akar terhadap pucuk pada genotip BRS-330 dengan 100 ppm GA $\mathrm{G}_{3}$ pada kondisi stres kekeringan.

Mengingat peran penting priming dalam mengurangi dampak cekaman kekeringan maka dilakukan penelitian yang bertujuan untuk mengetahui pengaruh osmopriming benih terhadap pertumbuhan dan morfofisiologi tanaman kangkung darat (Ipomoea reptans Poir) pada cekaman kekeringan.

\section{BAHAN DAN METODE}

\section{Percobaan di Laboratorium}

Penelitian dilakukan pada bulan September 2015 sampai April 2016 di Laboratorium Fisiologi Tumbuhan dan FALITMA Fakultas Biologi Universitas Gadjah Mada. Bahan yang digunakan adalah benih kangkung darat 
(Ipomoea reptans Poir) varietas Kencana diperoleh dari PT. Raja Pilar Agrotama (masa kadaluwarsa: Oktober 2016) sebanyak 160 butir dan polyethylene glycol (PEG 6000) sebagai larutan osmotikum.

Perlakuan osmopriming benih terdiri atas 4 taraf yaitu 0\%, 5\%, 10\%, dan 15\% (w/v) PEG 6000 dengan 4 ulangan. Pembuatan larutan PEG 6000 konsentrasi 5\%, 10\%, 15\% dilakukan dengan cara melarutkan sebanyak $50 \mathrm{~g}, 100 \mathrm{~g}$, dan $150 \mathrm{~g}$ secara berturut-turut dengan 1,000 $\mathrm{ml}$ air. Untuk setiap konsentrasi digunakan 40 benih kangkung darat yang direndam dalam larutan PEG 6000 sebanyak $30 \mathrm{~mL}$ di dalam cawan petri berdiameter $12 \mathrm{~cm}$ selama 24 jam. Benih yang telah direndam kemudian dikeringanginkan di dalam cawan petri yang beralaskan kertas saring Whatman no.1 pada suhu ruang selama 24 jam untuk selanjutnya dikecambahkan. Pengecambahan benih berlangsung selama 10 hari.

Persentase berkecambah diukur berdasarkan persentase kecambah normal pada hari ke-10 setelah benih dikecambahkan sedangkan keserempakan berkecambah diukur berdasarkan persentase kecambah normal kuat pada hari ke-10 setelah benih dikecambahkan. Benih yang berkecambah normal kuat yaitu benih yang berkecambah dengan bagian-bagiannya yang lengkap serta mempunyai penampilan yang lebih kuat perkecambahannya melebihi rata-rata kecambah normal lainnya (hipokotilnya lebih panjang dan kekar, akarnya lebih panjang atau lebih banyak, dan plumulanya lebih besar atau lebih lebar). Peubah kecepatan berkecambah diukur berdasarkan jumlah tambahan kecambah normal setiap hari. Pengamatan dilakukan pada hari ke-3 hingga hari ke-10.

\section{Percobaan di Lapang}

Seedling yang berumur 10 hari dari hasil pengecambahan benih dipindahkan ke media tanam sebanyak $1.5 \mathrm{~kg}$ berisi tanah dan pupuk kandang dengan perbandingan 2.5: 1 di dalam polibag berukuran $10 \times 19$ $\mathrm{cm}$ dengan diameter $12 \mathrm{~cm}$. Perlakuan penyiraman dimulai setelah tanaman berumur 14 hari. Rancangan penelitian yang digunakan adalah rancangan acak kelompok (RAK) faktorial dengan 2 faktor perlakuan dan 4 ulangan. Faktor pertama adalah perlakuan osmopriming benih yang terdiri atas 4 taraf yaitu $\mathrm{O} 0$ (benih kering/kontrol), O1 (5\% (w/v) PEG), O2 (10\% (w/v) PEG), dan O3 (15\% (w/v) PEG). Faktor kedua adalah perlakuan cekaman kekeringan yang terdiri atas 3 taraf yaitu K0 (penyiraman 1 hari sekali/kontrol), $\mathrm{K} 1$ (penyiraman 3 hari sekali), dan K2 (penyiraman 5 hari sekali). Banyaknya air penyiraman berdasarkan banyaknya air ketika kapasitas lapang tercapai yaitu setelah 2 atau 3 hari sejak terjadi pembasahan atau hujan lebat dan setelah drainase berhenti atau potensial gravitasi sama dengan nol (Utomo et al., 2016). Pembasahan dilakukan dengan menyiram media tanah kering dalam polibag dengan air sebanyak 1,000 ml dan didiamkan selama 3 x 24 jam hingga air berhenti menetes. Banyaknya air ketika kapasitas lapang ditentukan dengan cara menghitung banyaknya air yang digunakan untuk menyiram dikurangi dengan banyaknya air yang menetes yaitu $1,000 \mathrm{~mL}-850 \mathrm{~mL}=150 \mathrm{~mL}$. Volume tersebut dikontrol untuk semua perlakuan selama 40 hari penelitian berlangsung.

Jumlah satuan percobaan adalah 4 (PEG) x 3 (kekeringan) x 4 (ulangan) dengan setiap satuan percobaan sebanyak 2 tanaman sehingga jumlah keseluruhan sampel tanaman adalah 96 tanaman dan tanaman ditempatkan di rumah kaca dengan kisaran suhu $33-35{ }^{\circ} \mathrm{C}$ dan kelembaban 70-80\%. Peubah yang diamati adalah panjang akar, bobot kering akar, bobot kering tajuk, kadar klorofil, serta kadar prolin. Pengujian kadar klorofil dan prolin menggunakan sampel daun ke-3 dari tanaman kangkung yang berumur 40 hari setelah tanam. Pengamatan peubah panjang akar, bobot kering akar, dan bobot kering tajuk juga dilakukan pada umur tanaman 40 hari setelah tanam.

Semua data dianalisis menggunakan analisis sidik ragam satu jalur (one-way analysis of variance) untuk peubah perkecambahan dan dua jalur (two-way analysis of variance) untuk peubah pertumbuhan dan morfofisiologi. Data hasil penelitian yang berpengaruh nyata dilanjutkan dengan uji beda rataan berdasarkan uji DMRT (Duncan's Multiple Range Test) pada taraf kepercayaan 95\% ( $\alpha=$ $5 \%$ ). Hubungan antar peubah dianalisis menggunakan analisis korelasi dan regresi dalam program SPSS 16.0 dan Microsoft Excel.

\section{HASIL DAN PEMBAHASAN}

\section{Perkecambahan Benih}

Persentase perkecambahan, kecepatan berkecambah, dan keserempakan berkecambah pada benih kangkung darat (Ipomoea reptans Poir) yang diberikan perlakuan osmopriming dengan PEG 6000 menunjukkan hasil yang berbeda nyata dibandingkan dengan kontrol (Tabel 1). Hal tersebut menunjukkan bahwa osmopriming dengan PEG mampu meningkatkan secara signifikan semua peubah perkecambahan dibandingkan kontrol dengan nilai maksimum diperoleh pada perlakuan konsentrasi PEG $15 \%$.

Hasil tersebut sesuai dengan penelitian yang dilakukan oleh Tian et al. (2014) yang menunjukkan bahwa osmopriming dengan PEG $15 \%$ pada biji jagung dapat meningkatkan secara signifikan laju imbibisi air pada saat priming, persentase perkecambahan, dan kecepatan perkecambahan dibandingkan dengan kontrol (tanpa perlakuan). Osmopriming dengan PEG meningkatkan persentase perkecambahan, indeks perkecambahan, serta menurunkan rerata waktu perkecambahan secara signifikan dibandingkan dengan kontrol pada biji bunga matahari (ElSaidy et al., 2011) dan biji jagung (Khan et al., 2017).

Peningkatan persentase perkecambahan, kecepatan berkecambah, dan keserempakan berkecambah pada perlakuan osmopriming tersebut disebabkan oleh efek priming dalam meningkatkan berbagai aktivitas metabolik dalam proses perkecambahan meliputi respirasi, metabolisme energi, dan mobilisasi cadangan makanan. Priming meningkatkan produksi ATP, pemenuhan energi, dan rasio ATP/ADP, mengaktivasi atau mensintesis 
Tabel 1. Persentase berkecambah, kecepatan berkecambah, dan keserempakan berkecambah benih kangkung darat (Ipomoea reptans Poir) pada perlakuan osmopriming benih

\begin{tabular}{lccc}
\hline $\begin{array}{l}\text { Osmopriming benih PEG } \\
(\%)\end{array}$ & $\begin{array}{c}\text { Persentase berkecambah } \\
(\%)\end{array}$ & $\begin{array}{c}\text { Kecepatan berkecambah } \\
\left(\% \text { etmal }^{-1}\right)\end{array}$ & $\begin{array}{c}\text { Keserempakan berkecambah } \\
(\%)\end{array}$ \\
\hline 0 & $85.00 \mathrm{c}$ & $18.62 \mathrm{c}$ & $62.50 \mathrm{c}$ \\
5 & $92.50 \mathrm{~b}$ & $23.06 \mathrm{~b}$ & $75.00 \mathrm{~b}$ \\
10 & $97.50 \mathrm{ab}$ & $24.33 \mathrm{~b}$ & $80.00 \mathrm{ab}$ \\
15 & $100.00 \mathrm{a}$ & $25.91 \mathrm{a}$ & $90.00 \mathrm{a}$ \\
\hline
\end{tabular}

Keterangan: Angka yang diikuti huruf yang sama pada kolom yang sama tidak berbeda nyata berdasarkan DMRT pada $\alpha=5 \%$

enzim yang berperan dalam mobilisasi cadangan protein, karbohidrat ( $\alpha$ dan $\beta$ amilase), dan lipid (Isocitrate lyase) serta meningkatkan aktivitas XTH (Xyloglucan endotrans hydrolase) dan meningkatkan produksi Endo beta mannase. XTH (Xyloglucan endotrans hydrolase) adalah enzim yang memiliki kemampuan untuk memecah xyloglucans dan Endo beta mannase adalah enzim yang terlibat dalam hidrolisis dinding sel endosperm yang kaya mannan. Kerja kedua enzim tersebut secara bersamaan mengakibatkan reorganisasi sitoskeleton yang penting untuk pelonggaran dinding sel. Perubahan tersebut akan mempercepat proses perkecambahan (Raj dan Raj, 2019).

\section{Pertumbuhan dan Morfofisiologi Tanaman}

Hasil analisis statistik menunjukkan adanya perbedaan yang nyata untuk nilai panjang akar dan bobot kering akar antara semua perlakuan osmopriming dengan kontrol pada interval penyiraman 3 hari sekali sedangkan pada interval penyiraman 1 dan 5 hari sekali, hanya perlakuan PEG $10 \%$ dan PEG 15\% yang berbeda nyata dengan kontrol. Sebaliknya, nilai bobot kering tajuk berbeda nyata antara perlakuan PEG 10\% dan PEG 15\% dengan kontrol pada interval penyiraman 5 hari sekali seperti yang terlihat pada Tabel 2. Nilai maksimum panjang akar, bobot kering akar, dan bobot kering tajuk ditunjukkan pada konsentrasi PEG $15 \%$. Hal tersebut dapat dilihat lebih jelas pada Gambar 1 dan 2 .

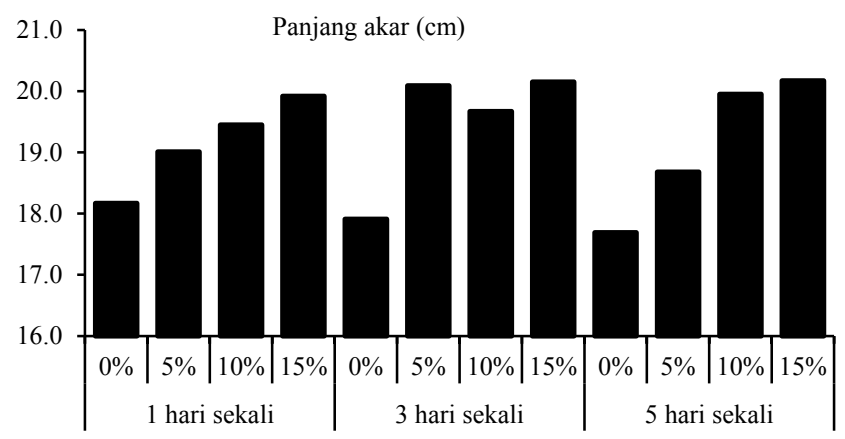

Gambar 1. Grafik pengaruh osmopriming benih terhadap panjang akar pada berbagai tingkat cekaman kekeringan
Hasil tersebut menunjukkan bahwa osmopriming dengan PEG 15\% meningkatkan secara signifikan panjang akar, bobot kering akar, dan bobot kering tajuk pada cekaman kekeringan. Hasil tersebut sebagaimana penelitian Tao et al. (2018) yang memberikan perlakuan osmopriming dengan PEG 6000 (-0.3MPa) pada biji Cleistogenes songorica memperlihatkan adanya peningkatan panjang akar yang signifikan dibandingkan dengan kontrol (tanpa perlakuan) dan PEG 15\% dapat meningkatkan bobot kering tajuk dan bobot kering akar pada biji jagung (Tian et al., 2014). Osmopriming juga dapat meningkatkan panjang akar dan kapasitas akar untuk berproliferasi pada kondisi stres kekeringan dibandingkan dengan kontrol pada biji jagung (Khan et al., 2015) dan biji barley (Amini, 2013) serta meningkatkan secara signifikan panjang akar dan bobot kering semaian dibandingkan dengan kontrol pada biji Vicia villosa (Kalsa dan Abebie, 2012), biji padi (Hussain et al., 2017), dan biji jagung (Khan et al., 2017).

Pengaruh priming dalam meningkatkan berbagai aktivitas metabolik dalam proses perkecambahan berkontribusi terhadap peningkatan panjang akar. Hal tersebut ditunjukkan dengan hubungan korelasi positif yang signifikan antara peubah persentase berkecambah, kecepatan berkecambah, dan keserempakan berkecambah terhadap panjang akar (Gambar 3, 4, dan 5).

Priming mempengaruhi sejumlah proses biokimiawi seperti hidrolisis, aktivasi enzim-enzim, replikasi DNA, serta sintesis protein dan RNA yang dapat meningkatkan

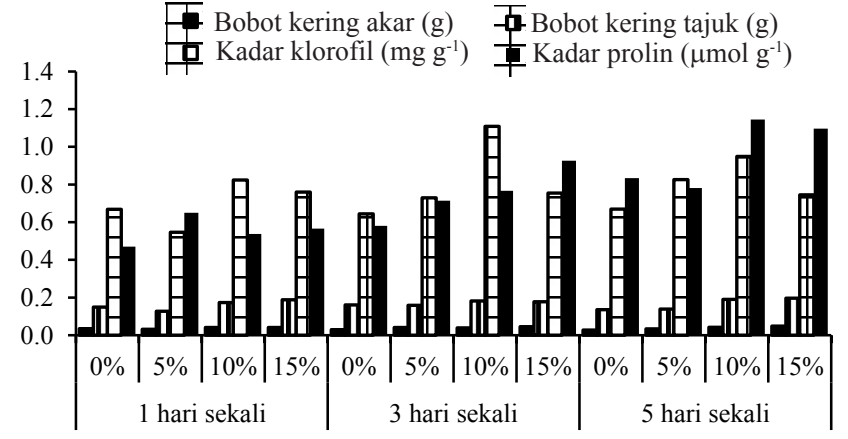

Gambar 2. Grafik pengaruh osmopriming benih terhadap bobot kering akar dan tajuk, kadar klorofil, dan kadar prolin pada berbagai tingkat cekaman kekeringan 


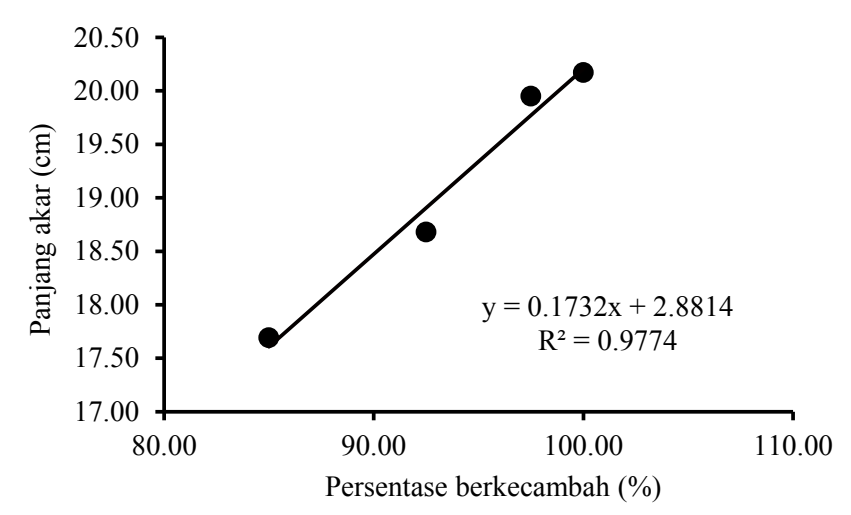

Gambar 3. Korelasi antara persentase berkecambah dan panjang akar pada berbagai konsentrasi osmopriming dan cekaman kekeringan 5 hari sekali

pertumbuhan embrio. Priming mampu mempercepat metabolisme cadangan makanan dan produksi metabolitmetabolit untuk perkecambahan serta meningkatkan aktivitas metabolik sehingga ketersediaan makanan untuk embrio lebih cepat dan lebih banyak seperti zat tepung dan gula yang berakibat pada pertumbuhan yang lebih cepat, lebih baik, dan seragam (Hussian et al., 2014).

Pengaruh osmopriming dalam meningkatkan bobot kering akar dan bobot kering tajuk pada kondisi cekaman kekeringan tersebut berkaitan dengan sistem perakaran. Hal tersebut ditunjukkan pada hubungan korelasi positif yang signifikan antara peubah panjang akar dengan bobot kering akar dan tajuk (Gambar 6 dan 7).

Dampak positif dari priming adalah sistem perakaran yang berkembang lebih baik dibandingkan dengan tanpa perlakuan (kontrol) pada cekaman kekeringan. Menurut Khan et al. (2015), sistem perakaran yang berkembang dengan baik dapat meningkatkan jangkauan ke area yang lebih luas pada lingkungan yang ketersediaan airnya terbatas sehingga air dan nutrisi menjadi lebih banyak tersedia bagi tanaman dan memungkinkan tanaman untuk meningkatkan aktivitas fotosintesis sehingga dapat mengakumulasi lebih banyak bahan kering dan hasil.

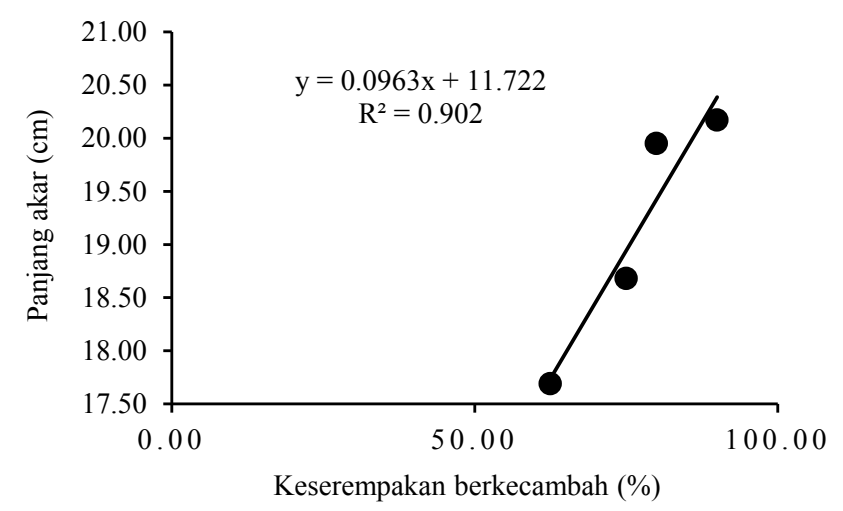

Gambar 5. Korelasi antara keserempakan berkecambah dan panjang akar pada berbagai konsentrasi osmopriming dan cekaman kekeringan 5 hari sekali

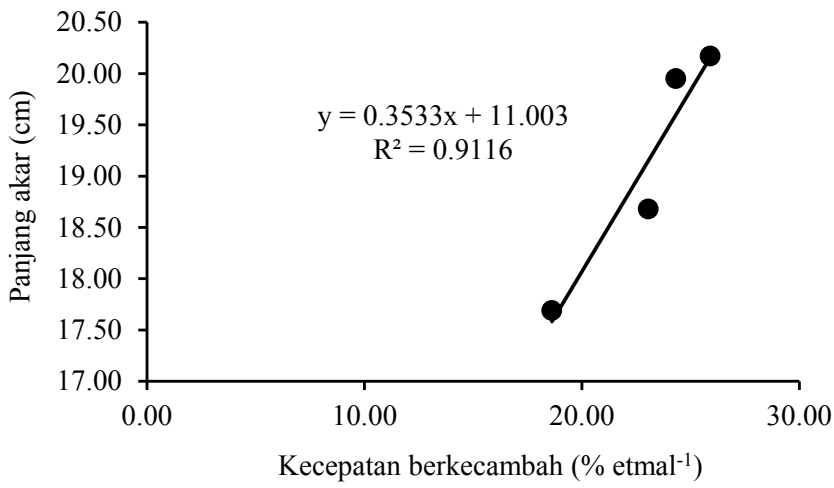

Gambar 4. Korelasi antara kecepatan berkecambah dan panjang akar pada berbagai konsentrasi osmopriming dan cekaman kekeringan 5 hari sekali

Osmopriming dengan PEG 10\% meningkatkan kadar klorofil secara signifikan dibandingkan dengan perlakuan lainnya dan kontrol pada interval penyiraman 1, 3, dan 5 hari sekali (Tabel 2). Hal tersebut dapat dilihat lebih jelas pada Gambar 2. Hasil tersebut menunjukkan bahwa PEG 10\% merupakan dosis optimum untuk meningkatkan kemampuan tanaman untuk tumbuh dengan meningkatnya kadar klorofil pada kondisi cekaman kekeringan. Hasil tersebut sesuai dengan penelitian Eivazi (2012) yang menunjukkan bahwa osmopriming dengan PEG $10 \%$ pada biji gandum dapat meningkatkan kadar klorofil pada tanaman gandum. Osmopriming dengan PEG dapat meningkatkan secara signifikan klorofil a dan b dan klorofil total dibandingkan dengan kontrol pada kondisi stres kekeringan pada biji gandum (Zhang et al., 2015) dan biji padi (Hussain et al., 2017).

Osmopriming meningkatkan kadar prolin secara signifikan yang ditunjukkan dengan adanya perbedaan yang nyata antara perlakuan PEG 15\% dibandingkan dengan kontrol pada interval penyiraman 3 dan 5 hari sekali (Tabel 2). Pengaruh tersebut dapat dilihat pada Gambar 2. Hal tersebut disebabkan oleh pengaruh osmopriming dalam proses perkecambahan yang ditunjukkan adanya hubungan

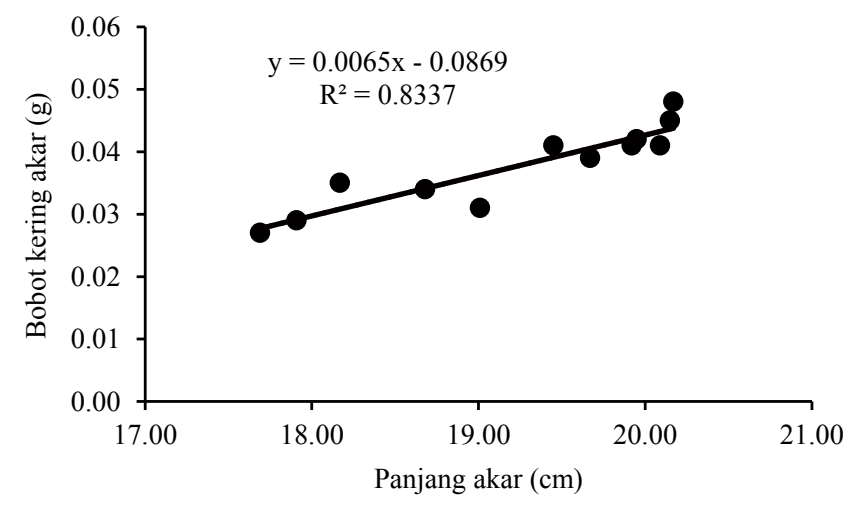

Gambar 6. Korelasi antara panjang akar dan bobot kering akar pada berbagai konsentrasi osmopriming dan tingkat cekaman kekeringan 
Tabel 2. Osmopriming benih terhadap pertumbuhan dan morfofisiologi tanaman kangkung darat (Ipomoea reptans Poir) pada kondisi kekeringan

\begin{tabular}{|c|c|c|c|c|c|}
\hline Perlakuan & $\begin{array}{l}\text { Panjang akar } \\
(\mathrm{cm})\end{array}$ & $\begin{array}{c}\text { Bobot kering akar } \\
(\mathrm{g})\end{array}$ & $\begin{array}{l}\text { Bobot kering tajuk } \\
(\mathrm{g})\end{array}$ & $\begin{array}{l}\text { Kadar klorofil } \\
\left(\mathrm{mg} \mathrm{g}^{-1}\right)\end{array}$ & $\begin{array}{l}\text { Kadar prolin } \\
\left.(\mu \mathrm{mol} \mathrm{g})^{-1}\right)\end{array}$ \\
\hline $\mathrm{O} 0$ & $17.92 d$ & $0.030 \mathrm{~d}$ & 0.148 bcde & $0.660 \mathrm{~d}$ & $0.628 \mathrm{c}$ \\
\hline $\mathrm{O} 1$ & $19.26 b c$ & $0.035 \mathrm{~cd}$ & $0.141 \mathrm{cde}$ & $0.700 \mathrm{~cd}$ & $0.715 b c$ \\
\hline $\mathrm{O} 2$ & $19.69 b$ & $0.041 \mathrm{ab}$ & $0.182 \mathrm{abc}$ & $0.961 b$ & $0.816 \mathrm{bc}$ \\
\hline $\mathrm{O} 3$ & $20.08 \mathrm{a}$ & $0.045 \mathrm{a}$ & $0.187 \mathrm{ab}$ & $0.753 \mathrm{c}$ & $0.862 b$ \\
\hline K0 & $19.14 \mathrm{c}$ & $0.037 \mathrm{bc}$ & $0.159 \mathrm{abcd}$ & $0.699 \mathrm{~cd}$ & $0.556 \mathrm{c}$ \\
\hline K1 & $19.46 b$ & $0.039 b c$ & $0.170 \mathrm{abcd}$ & $0.809 \mathrm{c}$ & $0.747 \mathrm{bc}$ \\
\hline $\mathrm{K} 2$ & $19.12 \mathrm{c}$ & $0.038 \mathrm{bc}$ & $0.165 \mathrm{abcd}$ & $0.797 \mathrm{c}$ & $0.964 b$ \\
\hline $\mathrm{OOK} 0$ & $18.17 \mathrm{~cd}$ & $0.035 \mathrm{~cd}$ & $0.149 \mathrm{bcde}$ & $0.668 \mathrm{~d}$ & $0.470 \mathrm{c}$ \\
\hline O1K0 & $19.01 \mathrm{bcd}$ & $0.031 \mathrm{~cd}$ & $0.127 \mathrm{e}$ & $0.546 \mathrm{~d}$ & $0.650 \mathrm{bc}$ \\
\hline $\mathrm{O} 2 \mathrm{~K} 0$ & $19.45 b$ & $0.041 \mathrm{ab}$ & $0.173 \mathrm{abcd}$ & $0.824 b c$ & $0.537 \mathrm{c}$ \\
\hline $\mathrm{O} 3 \mathrm{~K} 0$ & $19.92 \mathrm{ab}$ & $0.041 \mathrm{ab}$ & $0.188 \mathrm{ab}$ & $0.760 \mathrm{c}$ & $0.566 \mathrm{c}$ \\
\hline O0K1 & $17.91 \mathrm{~cd}$ & $0.029 d$ & $0.161 \mathrm{abcd}$ & $0.644 d$ & $0.580 \mathrm{c}$ \\
\hline O1K1 & $20.09 a$ & $0.041 \mathrm{ab}$ & 0.159abcde & $0.729 \mathrm{~cd}$ & $0.714 b c$ \\
\hline $\mathrm{O} 2 \mathrm{~K} 1$ & $19.67 b$ & $0.039 b c$ & $0.182 \mathrm{abc}$ & $1.109 \mathrm{a}$ & $0.767 b c$ \\
\hline $\mathrm{O} 3 \mathrm{~K} 1$ & $20.15 a$ & $0.045 \mathrm{a}$ & $0.177 \mathrm{abcd}$ & $0.754 \mathrm{c}$ & $0.926 b$ \\
\hline O0K2 & $17.69 d$ & $0.027 \mathrm{~d}$ & $0.135 \mathrm{de}$ & $0.669 \mathrm{~cd}$ & $0.834 \mathrm{bc}$ \\
\hline $\mathrm{O} 1 \mathrm{~K} 2$ & $18.68 \mathrm{bcd}$ & $0.034 \mathrm{~cd}$ & $0.139 \mathrm{cde}$ & $0.826 b c$ & $0.781 b c$ \\
\hline $\mathrm{O} 2 \mathrm{~K} 2$ & $19.95 \mathrm{ab}$ & $0.042 \mathrm{ab}$ & $0.190 \mathrm{ab}$ & $0.949 b$ & $1.145 \mathrm{a}$ \\
\hline $\mathrm{O} 3 \mathrm{~K} 2$ & $20.17 \mathrm{a}$ & $0.048 \mathrm{a}$ & $0.196 \mathrm{a}$ & $0.745 c$ & $1.096 \mathrm{a}$ \\
\hline
\end{tabular}

Keterangan: Angka yang diikuti oleh huruf yang sama pada faktor yang sama tidak berbeda nyata berdasarkan DMRT pada $\alpha=5 \%$. O0: benih kering (kontrol), O1 = 5\% (w/v) PEG; O2 = 10\% (w/v) PEG; O3 = 15\% (w/v) PEG; K0 = penyiraman 1 hari sekali (kontrol); $\mathrm{K} 1$ = penyiraman 3 hari sekali, K2: penyiraman 5 hari sekali

korelasi positif antara peubah persentase berkecambah, kecepatan berkecambah, dan keserempakan berkecambah terhadap kadar prolin (Gambar 8, 9, dan 10). Perlakuan osmopriming dapat meningkatkan prolin secara signifikan pada tingkat stres kekeringan -2.0, -3.0, dan -4.0 MPa pada biji kubis China (Yan, 2015). Dampak positif dari priming tersebut terhadap kadar prolin juga telah dibuktikan pada biji gandum (Tabassum et al., 2018), biji padi varietas Nagina-22 (N-22) dan Pusa-Sugandh-5 (PS-5) (Samota et

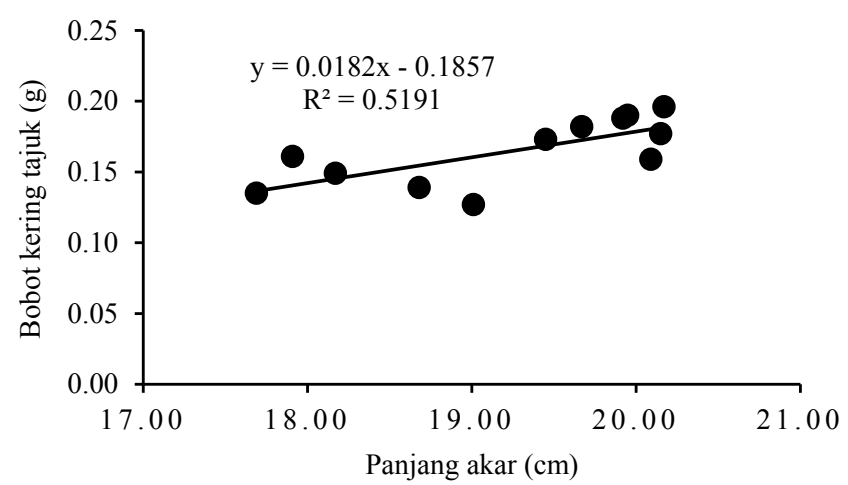

Gambar 7. Korelasi antara panjang akar dan bobot kering tajuk pada berbagai konsentrasi osmopriming dan tingkat cekaman kekeringan al., 2017), dan biji Trifolium repens cv. Ladino (Cao et al., 2018).

Prolin berfungsi dalam penyesuaian osmotik sel yaitu terakumulasinya prolin (dan zat terlarut lainnya) menyebabkan potensial osmotik sel menurun sehingga dapat berimbang dengan menurunnya potensial air di tanah, sementara turgor dan kandungan air dipertahankan (Verslues dan Sharma, 2010).

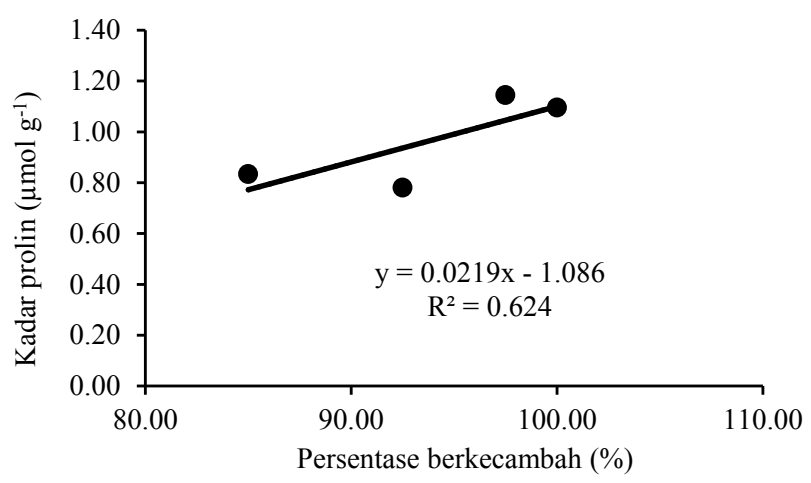

Gambar 8. Korelasi antara persentase berkecambah dan kadar prolin pada berbagai konsentrasi osmopriming dan cekaman kekeringan 5 hari sekali 


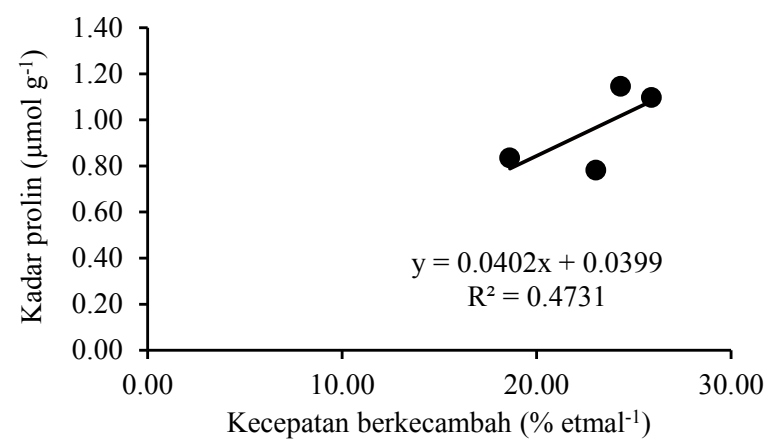

Gambar 9. Korelasi antara kecepatan berkecambah dan kadar prolin pada berbagai konsentrasi osmopriming dan cekaman kekeringan 5 hari sekali

\section{KESIMPULAN}

Osmopriming benih meningkatkan secara signifikan persentase berkecambah, kecepatan berkecambah, keserempakan berkecambah, panjang akar, bobot kering akar, bobot kering tajuk, kadar prolin dengan konsentrasi PEG $15 \%$ dan meningkatkan secara signifikan kadar klorofil dengan konsentrasi PEG $10 \%$ pada kondisi cekaman kekeringan. Osmopriming dapat mengurangi dampak yang ditimbulkan dari cekaman kekeringan dengan meningkatkan potensial perkecambahan, panjang akar, bobot kering akar dan tajuk, kadar klorofil, serta kadar prolin sehingga tanaman lebih tahan terhadap cekaman kekeringan.

\section{DAFTAR PUSTAKA}

Amini, R. 2013. Drought stress tolerance of barley (Hordeum vulgare L.) affected by priming with PEG. Int. J. Farm. Alli. Sci. 2:803-808.

Cao, Y., L. Liang, B. Cheng, Y. Dong, J. Wei, X. Tian, Y. Peng, Z. Li. 2018. Pretreatment with $\mathrm{NaCl}$ promotes the seed germination of white clover by affecting endogenous phytohormones, metabolic regulation, and dehydrin-encoded genes expression under water stress. Int. J. Mol. Sci. 19:1-15.

Chen, K., R. Arora. 2011. Dynamics of the antioxidant system during seed osmopriming, post-priming germination, and seedling establishment in spinach (Spinacia oleracea). Plant Sci.180:212-220.

Debbarma, M., S.P. Das. 2017. Priming of seed: Enhancing growth and development. Int. J. Curr. Microbiol. App. Sc. 6:2390-2396.

Eivazi, A. 2012. Induction of drought tolerance with seed priming in wheat cultivars (Triticum aestivum L.). Acta Agric. Slov. 99:21-29.

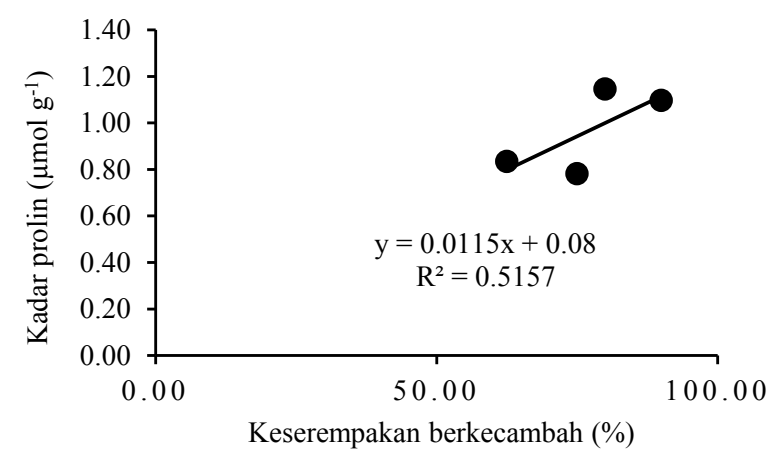

Gambar 10. Korelasi antara keserempakan berkecambah dan kadar prolin pada berbagai konsentrasi osmopriming dan cekaman kekeringan 5 hari sekali

El-Saidy, A.E.A., S. Farouk, H.M.A. El-Ghany. 2011. Evaluation of different seed priming on seedling growth, yield, and quality components in two sunflower (Helianthus annuus L.) cultivars. Trends Appl. Sci. Res. 6:977-991.

Erinnovita, M. Sari, D. Guntoro. 2008. Invigorasi benih untuk memperbaiki perkecambahan kacang panjang (Vigna unguiculata Hask. ssp. sesquipedalis) pada cekaman salinitas. Bul. Agron. 36:214-220.

Fitter, A.H., R.K.M. Hay. 2002. Environmental Physiology of Plants ${ }^{3 r d}$ Edition. Academic Press, San Diego, US.

Gorzi, A., H. Omidi, A.B. Bostani. 2018. Morphophysiological responses of stevia (Stevia rebaudiana Bertoni) to various priming treatments under drought stress. Appl. Ecol. Env. Res. 16:4753-4771.

Hussain, M., M. Farooq, D.J. Lee. 2017. Evaluating the role of seed priming in improving drought tolerance of pigmented and non-pigmented rice. J. Agro. Crop. Sci. 2017:1-8.

Hussian, I., R. Ahmad, M. Farooq, A. Rehman, M. Amin. 2014. Seed priming improves the performance of poor quality wheat seed under drought stress. App. Sci. Report 7:12-18.

Hussian, I., R. Ahmad, M. Farooq, A. Rehman, M. Amin, M. Abu Bakar. 2014. Seed priming: A tool to invigorate the seeds. Sci. Agri. 7:122-128.

Kalsa, K.K., B. Abebie. 2012. Influence of seed priming on seed germination and vigor traits of Vicia villosa ssp. dasycarpa (Ten). Afr. J. Agri. Res. 7:3202-3208.

Khan, M.B., M. Hussain, A. Raza, S. Farooq, K. Jabran. 2015. Seed priming with $\mathrm{CaCl}_{2}$ and ridge planting for improved drought resistance in maize. Turk. J. Agric. For. 39:193-203. 
Khan, A.Z., T. Shah, S. Khan, A. Rehman, H. Akbar, A. Muhammad, S.K. Khalil. 2017. Influence of seed invigoration techniques on germination and seedling vigor of maize (Zea mays L.). Cercet. Agron. Mold. 3:61-70.

Matsushima, K.I., J.I. Sakagami. 2013. Effects of seed hydropriming on germination and seedling vigor during emergence of rice under different soil moisture conditions. Am. J. Plant Sci. 4:1584-1593.

Pinheiro, C.L., H.T.N. Araujo, S.F. de Brito, M.d.S. Maia, J.d.S. Viana, S.M. Filho. 2018. Seed priming and tolerance to salt and water stress in divergent grain sorghum genotypes. Am. J. Plant Sci. 9:606-616.

Raj, A.B., S.K. Raj. 2019. Seed priming: An approach towards agricultural sustainability. J. Nat. Appl. Sci. 11:227-234.

Rao, K.V.M., A.S. Raghavendra, K.J. Reddy. 2006. Physiology and Molecular Biology of Stress Tolerance in Plants. Springer, Netherlands, NL.

Samota, M.K., M. Sasi, A. Singh. 2017. Impact of seed priming on proline content and antioxidant enzymes to mitigate drought stress in rice genotype. Int. J. Curr. Microbiol. App. Sci. 6:2459-2466.

Singh, A., R. Dahiru, M. Musa, B.S. Haliru. 2014. Effect of osmopriming duration on germination, emergence, and early growth of cowpea [Vigna unguiculata (L.) Walp] in the Sudan savanna of Nigeria. Int. J. Agron. 2014:1-4.

Sunarjono, H. 2013. Bertanam 36 Jenis Sayur. Penebar Swadaya, Jakarta, ID.
Tabassum, T., M. Farooq, R. Ahmad, A. Zohaib, A. Wahid, M. Shahid. 2018. Terminal drought and seed priming improves drought tolerance in wheat. Physiol. Mol. Biol. Plants 24:845-856.

Tao, Q., Lv. Yanyan, Q. Mo, M. Bai, Y. Han, Y. Wang. 2018. Impacts of priming on seed germination and seedling emergence of Cleistogenes songorica under drought stress. Seed Sci. Technol. 46:239-258.

Tian, Y., B. Guan, D. Zhou, J. Yu, G. Li, Y. Lou. 2014. Responses of seed germination, seedling growth, and seed yield traits to seed pretreatment in maize (Zea mays L.). Sci. World J. 4:1-8.

Utomo, M., Sudarsono, B. Rusman, T. Sabrina, J. Lumbanraja, Wawan. 2016. Ilmu tanah: Dasar-dasar dan Pengelolaan Edisi Pertama. Kencana, Jakarta, ID.

Verslues, P.E., S. Sharma. 2010. Proline metabolism and its implications for plant-environment interaction. The Arabidopsis Book. American Society of Plant Biologists, Rockville, US.

Yan, M. 2015. Seed priming stimulate germination and early seedling growth of Chinese cabbage under drought stress. S. Afr. J. Bot. 99:88-92.

Zhang, F., J. Yu, C.R. Johnston, Y. Wang, K. Zhu, F. Lu, Z. Zhang, J. Zou. 2015. Seed priming with polyethylene glycol induces physiological changes in sorghum [Sorghum bicolor (L.) Moench] seedlings under suboptimal soil moisture environments. Plos One 10:1-15. 